\title{
The Hockey Sweater: A Canadian Cross-Cultural Icon
}

\author{
Anne Hiebert Alton
}

The game of hockey in Canada far exceeds the realm of pastime or sport; it has come to symbolize a way of life in this nation... the game has served as a national symbol for a country whose identity is constantly scrutinized by its own people. Few other institutions in Canada have the unifying potential of hockey.

(Robidoux 2001, p.3)

\section{In any world menu, Canada must be considered the vichyssoise of nations - it's cold, half-French and difficult to stir. \\ Stuart Keate}

I $\mathrm{n}$ many ways the notion of Canadian identity is something constantly under construction-a work in 1 progress, with no perceived end or unified whole in sight. Canadian literary critic and theorist Northrop Frye once commented that '[b]ecause Canada was founded by two peoples, nobody could ever know what a hundred per cent Canadian was' (1982, p.68), and his statement is as accurate today as it was in 1982 when he wrote it-perhaps even more so, given Canada's current multicultural, rather than simply bicultural, identity. Nevertheless, one of Canada's strongest bifurcations in cultural identity has existed since the country's very beginnings, when it was created as 'a bicultural partnership between the "two founding races" of English and French' (Bell 1992, p.73).' Despite our age of nearly 150 years as a single country, we are still negotiating -or arguing, depending on one's perspective-about our identity as a nation, and one of the main points of contention is the question of how Québec and its desire to live as a distinct cultural community fits into the larger whole. ${ }^{2}$ This question is one that concerns all Canadians- French-speaking and English-speaking, eastern and western, female and male - and appears to be one of the few cultural elements we may all share. The other, of course, is hockey. Michael Robidoux is correct when he suggests that hockey in Canada is more than just a sport; the love of hockey is one of the things that makes us Canadians. And this love-or better yet, passion-for hockey is something that crosses both language and cultural boundaries. The cheer for the Toronto Maple Leafs- 'Go, Leafs, Go!'- sounds remarkably similar (especially when being sounded by 20,000 fans) to the chant for the Montréal Canadiens-'Can-a-diens! Can-a-diens!', while the announcer's roar 'He scores!' has the same intonation and unmistakable meaning as 'Marqué!'. Roch Carrier's and Sheldon Cohen's picture book The Hockey Sweater, the story of a young French Canadian boy's tribulations when he mistakenly receives a Toronto Maple Leafs hockey sweater instead of his coveted Montréal Canadiens sweater, exemplifies these two defining ideas of Canadian culturethe French-English tensions and the passion for hockeyand in doing so has become a symbol of Canadian identity.

The book itself has a rather unusual creative history. It began as a short story by Québécois writer Carrier published in 1979 in Les Enfants du Bonhomme dans la Lune, appearing in English the same year as The Hockey Sweater and other stories. In 1980, Carrier collaborated with Montréal illustrator and animator Cohen to create a short children's film entitled Le Chandail de Hockey / The Sweater, which won the British Academy Award along with nine other international film honours. ${ }^{3}$ In 1984 , Carrier and Cohen published a picture book version of the story, which became a classic of Canadian children's literature in both French-speaking and English-speaking parts of the country. However, it was the film that initially captured the attention of all Canadians. Addressing the whole country through the deceptively simple voice of a children's story, The Sweater subtly portrays the tensions between French Canadian and English Canadian culture and, by doing so, defines many of the contradictions that make up Canada.

Until relatively recently, Carrier was not known as a children's author; instead, he was recognized as one of Québec's most prolific and successful writers of novels, plays, poetry, and short stories for adults. His novelsincluding La Guerre, Yes Sir! (1968), Floralie, Ou Es-Tu? (Floralie, Where Are You?) (1969), and $I n^{\prime} y$ a pas de Pays sans Grand Pere (No Country without Grandfathers) (1977)-are taught in schools and universities world-wide in both French and English, and he has won a number of awards for his writing, including the Grand Prix Litteraire de la Ville de Montréal, le Prix littéraire de la Province de

Papers 12: 22002

Copyright of Full Text rests with the original copyright owner and, except as permitted under the Copyright Act 1968, copying this copyright material is prohibited without the permission of the owner or is prohibited without the permission of the owner or
its exclusive licensee or agent or by way of a licence from Copyright Agency Limited. For information about such licences contact Copyright Agency Limited on (02) 93947600 (ph) or (02) 9394760 (fax) 
Québec (in 1964 for his first novel, Jolis deuils), and the Stephen Leacock Medal for humour (1991). In contrast, Cohen is known primarily for his picture book versions of four of Carrier's short stories. In addition to Le Chandail de Hockey / The Hockey Sweater (1984), the two have published three other picture books: Un Champion / The Boxing Champion (1991), which won Canada's Governor General's award for children's literature illustration, Le Plus Long Circuit / The Longest Home Run (1993), which was a runner-up for the Govemor General's award, and $L e$ Joucuer de Basket-Ball / The Basketball Player (1996). While Carrier and Cohen have made quite a reputation for themselves within children's literature circles over the last decade, their masterpiece remains The Hockey' Sweater.

One of the most intriguing elements of both the film and picture book versions of the tale appears in the nearly universai response they elicit, which tends to be variations of 'so that's what Canada is about!'. Such a response certainly is appropriate, at least in some ways: Canada is a northern country in which snow and ice play a large part of winter, and hockey is the unofficial national sport (the official title goes to lacrosse, though I don't know a single Canadian who plays it). However, Canada is also a bilingual country, and the intersections and tensions between French and English languages and cultures also form a crucial part of Canada's national identity. Carrier writes in his native Québécois (Canadian French), and his works are translated into English by his translator, Sheila Fischman. The collection in which the original short story of 'The Hockey Sweater' appeared was the sixth volume of his work she translated. Max Walkley (2000) suggests that Carrier's language in 'The Hockey Sweater' has been influenced by joual, a colloquial variant of Québécois adopted by a number of French Canadian writers in the 1960s and early 70s; Wayne Grady adds that this variant is somewhat difficult for the English ear to adapt to ('Roch', p.63). However, a number of other critics disagree, suggesting that although Carrier's writing 'stylizes and heightens the speech of rural Québec' he is specifically not adopting the joual form ('Roch', p.63). The latter critics seem more convincing. for Fischman appears quite responsive to Carrier's style and language, rendering the English translation very accessible while still leaving overtones of rura! Québec. For example, Carrier's opening sentence in the film, which appears on the second page of the English picture book, reads: 'I remember very well the winter of 1946.' The placement of the adverb immediately after the verb, rather than after the object (as it would be in English). apparently reflects the direct translation of the French version: in French the sentence should read 'Je me souviens trés bien l'hiver de mille neufcent quarante-six.' Curiously, in the French version of the picture book this sentence is omitted; instead, the paragraph begins with a sentencethe second sentence of the paragraph in the English version-referring to the boys wearing hockey sweaters like Maurice Richard's. This addition suggests a certain cultural difference between English-speaking and Frenchspeaking audiences hearing the story and evokes a particularly Québécois flavor for non-Québécois listeners. Moreover, it also assumes a knowledge of Québécois cultural heritage on the part of French Canadian readers: by omitting the sentence in the original French version, Carrier seems to be making the assumption that Québécois readers, at least, will be aware of the time that Maurice Richard was first playing for the Montréal Canadiens hockey team.

Carrier's and Fischman's decision to begin the English version differently from the French version highlights not only Canada's ever-present dialogue about issues of translation-Walkley notes Canada's strong reputation in its universities for studies on theoretical and practical problems in translation-but also the tension between the French and English Canadian cultures. The overtones of Québécois language and culture are reinforced even more strongly in the film than in the picture book, mainly because of the element of sound. The film was released in two versions, one in French and the other in English, both with Carrier narrating and a background track of music. Once having heard Carrier's voice, it is virtually impossible to read the story silently without falling into the lilt and cadence present in his language. For example, when reading the section where Roch's mother is writing to Monsieur Eaton, the memory of Carrier's voice forces me to read the passage cioser to his intonation than my own: 'Dear Monsieur Eaton, / Would you be so kind / as to send me / a Canadiens' / hockey/sweater / for my son, / Roch, / who is ten years old / and a little bit tall / for his age.' The sentence feels more staccato after hearing Carrier's voice than it would have before. This happens repeatedly 
throughout the text: in another place, one cannot help but hear Carrier's voice passionately saying 'We were ten players / all wearing the uniform / of the Montreal / Canadiens, / all with the same / buming / enthusiasm.' Carrier's Québécois accent and intonation give the story an even stronger feeling of belonging to a particular culture. The lively folk-music accompanying the film adds a further feeling of cultural veracity, and makes the audience think of Ste. Justine as the epitome of a French Canadian town in the middle of winter.

The tension between English and French appears in areas other than language; indeed, this tension is one of the underlying elements of both the film and the book, just as it is one of the underlying elements of Canada itself. One of the more subtle in-jokes appears with the portrayal of the curate. In both the picture book and the til $\mathrm{m}$, he is portrayed as being utterly huge, and he towers over the boys whenever they see him, perhaps suggesting the authority the church carried in this small town (see page 8 ). In the film, however, Cohen appears to be caricaturizing the former Prime Minister of Canada, the late Pierre Elliot Trudeau. Just before the start of the hockey game, the curate cum referee pushes up his glasses and wipes his nose in a gesture similar to one of Trudeau's. While this is a sign of the 1980s, when the film was made, rather than the 1940s, when the story is set, it is both a memorable and recognizable gesture to a Canadian. Less subtle is the portrayal of the rivalry between the Montréal Canadiens and the Toronto Maple Leafs - and, by implication, the rivalry between French Canada and English Canada. At the opening of the film, the narrator mentions that the Toronto (English) team is always losing to the Montreal (French) team, a comment that appears mid-way through the book. ${ }^{5}$ Later, when Roch wants to exchange his Maple Leafs sweater for a Canadiens sweater, in the book his mother'comments, 'Monsieur Eaton understands French perfectly, but he's English and he's going to be insulted because he likes the Maple Leafs.' In contrast, in the film his mother says simply 'Monsieur Eaton can read French perfectly, but he is English, and he's going to be insulted,' leaving it up to the audience to determine the reason for Monsieur Eaton's reaction, and perhaps implying that he will be insulted because he is English and that not liking the Maple Leafs is somehow a slur on English Canada. Moreover, in both the film and the book Monsieur Eaton appears sitting at a desk drinking tea, the ultimate English drink.

The English-French tension is brought to a head in the scene of the hockey game near the end, when Roch is ostracized for having the audacity to appear wearing the enemy team's sweater and loses his temper over receiving what he considers an unfair penalty. The order of the curate's words are reversed in the film and the book, but both have the same meaning: 'My child ... just because you're wearing a new Toronto Maple Leafs sweater, it doesn' $t$ mean you're going to make the laws around here.' The implication, of course, is that the curate blames Roch for apparently assuming that his English sweater will give him special privileges over those wearing French sweaters. Roch is punished not only for assuming that being English gives him more rights than being French-hitting at the heart of the conflict between French and English Canadabut also for showing a supposed lack of allegiance to the Montréal Canadiens, Québec, and French Canada as a whole. Lest this seem to be stretching things too far, it bears remembering that, in an interview conducted in the 1970s, Carrier commented on his belief that the conflict between French and English in Canada is inevitable, and likened the situation to that of Northern Ireland and England ('Roch Carrier', pp.37-38). Finally, the ambiguity of the ending also suggests a subversive subtext: the curate comments that 'a good boy never loses his temper. Take off your skates and go to the church and ask God to forgive you.' Although one could assume that Roch is being sent to pray for forgiveness for losing his temper, it is impossible not to wonder whether the curate is also sending him to ask for forgiveness for appearing to think that being English gives him the right to make rules.

While the film and the picture book versions of The Hockey' Sweater suggest some of the conflicts between French and English Canada, both go much further in terms of commenting on Canada as a whole and the culture of childhood in general. In many ways, this story demonstrates what it meant to be a Canadian child, not just in Québec but throughout Canada, in the 1940s. At that time in our history and in many households across the country, the radio broadcast of Hockey Night in Canada was one of the major events of the week, and some might argue the 


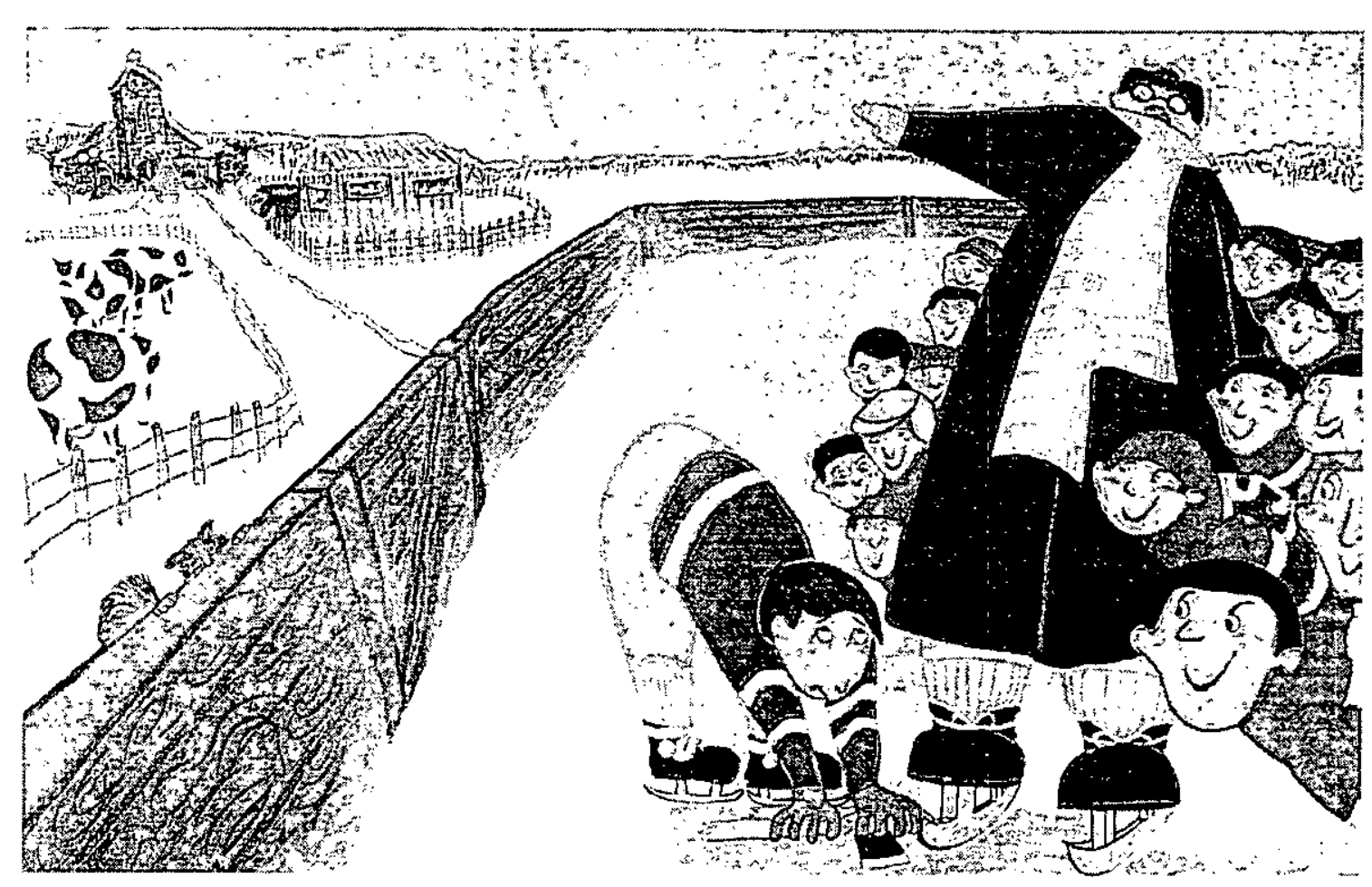

Illustration by Sheldon Cohen from The Hockey Swealer 1984 by Roch Carrier, Tundra Books Toronto

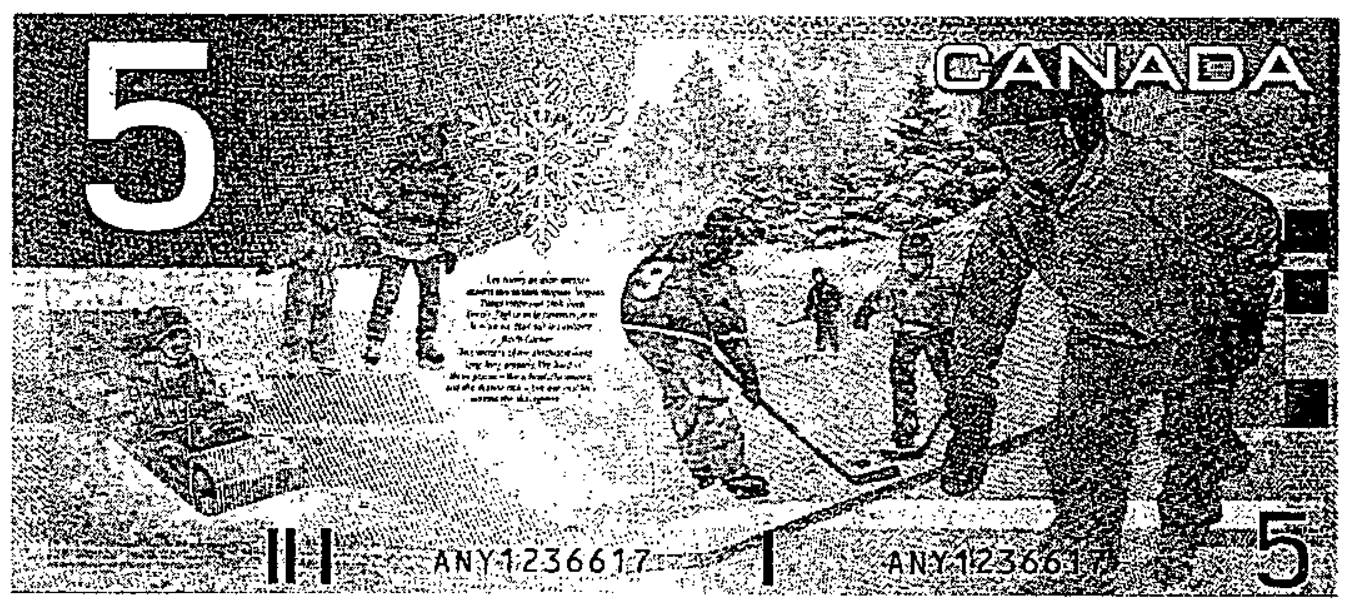


television broadcast of the same show still is. Hockey was (and is) followed with an almost religious passion, as Carrier's opening comment suggests: while the church was ever-present, even more important-at least in the children's eyes-were the Saturday night hockey games. Most religions have deities, and for followers of the Montréal Canadiens, Maurice Richard happily fit the description. Richard was one of hockey's greatest legends: during the 1944-45 season (two years before the story begins), he became the first player in NHL history to score fifty goals in fifty games. In that same season he scored all five goals in a five to one victory over Toronto, which perhaps accounts for Roch's perspective that the Canadiens were 'always' beating the Maple Leafs. His elevation to the status of hero can be seen in the way the boys do everything to emulate him: combing their hair, lacing their skates, taping their sticks, and praying to God to help them play hockey as well as Richard.

The ways in which this particular scene is rendered in the picture book and the film bring very different strengths to the story. The energetic movement and aural imagery of the film cannot possibly be duplicated in a picture book, and Cohen wisely does not try to do so. For example, early in the film Cohen portrays the boys using hair glue to keep their hair in place, and accompanies the movement of the boys' hands with a 'glomping' sound not indicated in the text. Moments later, he pictures them pointing out a variety of Maurice Richard's statistics, dressing like him and-in their imaginations-becoming him while on the ice as they skate round the back of the goalie's net. In the picture book Cohen chooses not to reproduce these multiple images. Instead, he focuses on the locker room, with a couple of boys in front of the mirror combing their hair, and another boy using his hockey stick as a pointer to highlight the statistics on Maurice Richard's 'poster. Although the illustration lacks the movement and sound of the film, its detail more than makes up for the loss: the reader can linger over the illustration, gradually noticing such elements as the black and white photographs on the walls, the sweaters with the number nine on their backs, the various items of winter clothing strewn around the room, the young boy taping his hockey stick, and the fire in the stove melting the ice on the windows. While the images of the film flash past too quickly to notice such details, the picture book allows for the time to read deeper meaning into the picture, such as the Canadiens' winning of the Stanley Cup (in the photograph of Maurice Richard in his number nine sweater holding the Cup), ${ }^{6}$ or the practice of collecting hockey cards (with the boy on the floor looking through his box of cards).

Clearly Richard is a figure of heroic proportions to the boys of Ste. Justine. This becomes even more apparent with his presence in the film, when he appears in Roch's imagination in a bubble over his shoulder to support Roch's stance against wearing the Toronto Maple Leafs sweater. His presence seems to give Roch courage in his conviction that he is doing the right thing to protest, such as when he leers and frowns at Roch's mother when she says 'You are not Maurice Richard' and when he supportively drapes his arm across Roch's shoulders and nods when Roch replies, 'You'll never make me put in my head to wear a Toronto Maple Leafs sweater!' At the very end, Richard appears to Roch almost like a god to shake his hand in congratulation for praying for 'a hundred million moths' to consume the offensive sweater, thus vanquishing the Maple Leafs once again. In some senses this reflects the reality of how he was regarded by entire generations of Canadians: when Maurice Richard passed away on 27 May 2000 , the whole country, both inside and outside of Québec, went into mourning. He was given a state funeral (the first time in Canadian history an athlete was so honoured); flags were lowered to halfmast as Québec's National Assembly was suspended for a day; and the funeral mass that was held at Notre Dame Basilica in Montréal was broadcast live throughout Canada. As a national hockey hero, Richard was a symbol who crossed barriers between east and west, local and national, adult and child, and-most significantly-French and English. While this may seem contradictory, at least in terms of Carrier's story, it is nevertheless true: while in the child's fantasy Richard belongs entirely to Québec, he was equally revered throughout Canada. Part of this may be because during the 1930s and 1940s it depended on which radio broadcast one received as to whether one supported Toronto or Montréal (at this time they were the only two Canadian teams of the six teams in the $\mathrm{NHL}$ ); ${ }^{7}$ some regions of both Manitoba and Ontario, for instance, received the Montréal games while others received the Toronto games. Even more importantly, however, for many fans 
the Canadiens represented what hockey was all about: the passionate, free-flowing style of skating, combined with the almost super-human ability to beat the odds and score a goal. Maurice Richard, who played his entire career with the Canadiens, was the epitome of that style; for him it wasn't enough to play hockey well, he played it passionately, and this is what attracted the attention and the reverence of the Canadian public.

Like Maurice Richard, The Hockey Sweater crosses many of these barriers. In addition to appealing to both French Canadian and English Canadian audiences, and to providing a subtle commentary on the tensions between them, the story also blurs the boundaries between child and adult. Certainly it sums up many of the experiences of childhood. Carrier and Cohen recreate the feelings of wanting to emulate one's sports hero and of wanting to conform and wear the 'right' sort of clothing, as well as demonstrate the consequences of not fitting in. For example, when Roch appears at the rink wearing the despised Maple Leafs sweater, Cohen exactly captures the looks on Roch's friends' faces, which range from shock and surprise to annoyance and anger. Even the curate/referee looks to be amused in a supercilious kind of way. Roch himself looks uncomiortable and embarrassed. In the next frame, Cohen perfectly renders Roch's feelings of outrage as he puffs himself up to shout at the referee, along with the gloating and smug expressions on his friends' faces in the background. Finally, Cohen catches Roch's feelings of helplessness when faced with adult authority. In both the film and the book, the curate looms over Roch and the rest of the boys, bringing to mind an image of the tall, dark shadow of adulthood. This evokes the childhood experience of feeling helpless when confronted by an adult who can force one to do as one is told. However, what follows evokes the rest of this experience: while Roch obeys the curate's orders and goes to the church to pray, instead of praying for forgiveness he prays for the solution to his dilemma - the moths to eat up what he sees as the cause of his troubles. This ending is humorous precisely because it is so typically child-like and yet so completely unexpected. We, as adults, laugh in delight because the ending is absolutely right in terms of a gesture of rebellion against the established order, but we are able to laugh for the simple reason that we are already a part of that order, and so can recognize it.

This brings us to the heart of the tension between the childlike experience of the story and the adult insights it provides. Michael Darling has suggested that this doublenarrative voice, simultaneously child and adult, creates a friction between adult and child states, where the adult wants to abandon adulthood and return to innocence. However, Darling continues, this in itself is an assertion of adulthood, since the child-state is presumed to be one of innocence and thus the child has no need to retum to it, never having left it ('Roch Carrier', p.78). It is this conflict between the two states that makes the story work. Although Carrier recreates scenes from his childhood throughout the story, his stance as adult narrator gives his audience the divided perspective which allows the story's irony-and its pivotal point-to exist. In the end, Roch does as he is told, but only to a point, which allows him to stay true to his identity as a child. He does not change his allegiance to his hero, Maurice Richard, and he is vindicated not only by the fantasy Richard's approval (in the film) but also by the audience, who feel relieved and delighted that Roch has not done the 'adult' thing and given in to the apparent voice of reason, but instead has remained a child behaving in what we (as adults) perceive as being a typically childlike manner.

Carrier once commented that the only way of being international is to be very national' ('Roch Carrier', p.46), ${ }^{\text {, }}$ and The Hockey Sweater succeeds in achieving a sort of mythic reality in terms of its commentary on Canadian childhood and identity. It is not much of a stretch to imagine a similar sort of tale being spun about a young lad in small-town Ontario or Saskatchewan receiving the wrong team's sweater and responding in a similar manner. The excitement associated with the Saturday night hockey game and the last-minute winning goal scored by the heroic player could just as easily happen in other parts of Canada (some of Wayne Gretzky's more exciting goals for the Edmonton Oilers a decade ago spring to mind) or, for that matter, in other parts of the world: nearly everyone remembers the feeling of magically becoming his or her hero for a moment while excelling at a game or during a performance. Other moments, such as Roch's skating up to the referee and stopping with a flourish of sprayed ice, or 
his excitement when he receives the package containing the sweater and carries it home holding it above his head, evoke both national and universal images of what it means to be a child. In terms of national identity, Roch's passion for hockey is something that both English Canadians and French Canadians relate to easily, for the dream of playing professional hockey is, at least for boys, the epitome of expressing what it means to be truly Canadian (Robidoux 2001 , p.47). From a universal perspective, his fantasy about Maurice Richard's partisanship suggests not only the sense of the ease with which children seem to enter their imaginative worlds, but also the childlike way of viewing issues from a particular perspective and ignoring the possibility of other interpretations. Whatever Roch believes - or chooses to remember - about the Canadiens always winning, ' $[\mathrm{t}$ ] he Toronto Maple Leafs... were the dominant team of the 1940s, winning the Stanley Cup 6 times in 10 years' (Marsh, 1985, p. 824). However, his memory of Maurice Richard's prowess as a hockey player is accurate: 'But Maurice "Rocket" Richard of the Canadiens was clearly the outstanding offensive player, scoring 50 goals in 50 games in 1944-45' (Marsh, 1985, p. 824). Roch's experience, particularly when placed in its historical context, epitomizes the contradictions that make up Caradian cultural identity.

Roch Carrier has been referred to as 'the mythmaker of Québec rural life' ('Roch Carrier', p.62). With the film and picture book versions of The Hockey Sweater, he and Sheldon Cohen have become mythmakers of Canadian childhood, both French and English. While the story portrays a vision of idealized village life in rural Québec a half century ago, it also highlights some of the inherently paradoxical elements of Canada's cultural identity. For those of us raised in the 1960s and 70s, under Trudeau's dream of creating a bilingual nation, we are caught in the bind of feeling that, on the one hand, we have both an English and French cultural heritage while, on the other hand, the two are inherently separate worlds. This tension, or contradiction, has been part of Canada's cultural heritage since 1867 and in many ways it has become part of what defines Canada. Similarly, in The Hockey Sweater the tension between the dual perspectives - of French Canada and English Canada, and of the child's voice and the adult narrator-creates the ironic key to the story. In the end, it takes the audience's recognition of the tensions between the two to achieve meaning, and this recognition comes via not only art but the understanding of the significance that the game of hockey has for all Canadians. While Roch's narrative is told from a Québécois point of view, Canadians can relate to not only the story's political implications in terms of the on-going tensions between English Canada and French Canada, but also its cultural significance in terms of the importance of hockey to us as a nation. This is reinforced when looking at the back of the new Canadian $\$ 5.00$ bill (see page 8 ), which carries an image of boys playing hockey outdoors: one of the players is wearing a hockey sweater with the number nine on its back-Maurice Richard's number, which Carrier makes a point of discussing in the story-and just to the left appears a quotation in both French and English of the first two sentences from The Hockey Sweater:

Les hivers de mon enfance étaient des saisons longues, longues. Nous vivions en trois lieux: l'école, l'église et la patinoire; mais la vraie vie était sur la patinoire.

\section{Roch Carrier}

The winters of my childhood were long, long seasons. We lived in three places-the school, the church and the skating-rink-but our real life was on the skating-rink.

Whatever our tensions, as Canadians our passion for hockey is something that transcends linguistic and cultural divisions, perhaps making us more truly a nation than we realise.

\section{NOTES}

1. The French came to what is now known as Canada around 1535; in 1760, after the Conquest--Britain's acquisition of the new territory through the Seven Years' War (1756-63), during which England's General James Wolfe defeated France's General Louis Montcalm in the Battle of the Plains of Abraham. Britain guaranteed the French settlers a number of rights, including the right to continue to own property and the freedom of religion. When the British divided the colony into Upper Canada and Lower Canada in 1792 (the Constitution Act), they tended to favour settlement in Upper Canada (today's province of Ontario), while the 
majority of French settlers inhabited Lower Canada (today's province of Québec). A number of social and economic stresses during the early 1800 s increased the already existing animosity between the Francophone and Anglophone communities, giving rise during the 1820 s and 1830 s to a number of French rebellions: while the British attempted to halt these rebellions with the 1840 Act of Union, which in 1841 unified the two provinces into a single colony, the tensions remained as French-speaking communities continued to insist on their right to live as a distinct cultural group. With the BNA Act (British North America Act) of 1867Canada's year of Confederation-Britain declared Салаda a Dominion, and Québec was guaranteed certain freedoms of self-determination within Canada, such as the right to retain the French language, the freedom of religion, and a separate legal system. The most significant of these rights was language: English and French were given equal legal footing in Parliament, although English tended to dominate both there and in the public service. Despite the legalities, Confederation had the effect of making many French Canadian people feel as though they had become a minority in the country that they founded (Thomson 1995, p. 75).

2. This question has been a major topic of discussion since the 1940s, when Québec started to become more economically and politically active. During the Quiet Revolution of the 1960s, French Canadian nationalism grew particularly strong and several political parties proposed a variety of social frameworks that, at their extreme, suggested complete separation from Canada. Near the end of that decade, Prime Minister Pierre Trudeau - a passionate Canadian nationalist - enacted huge reforms in education as well as law, including making Canada an officially bilingual country in order to unify Canada into a single nation that spoke both French and English. However, in 1977 Québec adopted the French Language Charter, which made French the sole official language of Québec. In 1982, when Canada's new Constitution (the Canadian Charter of Rights and Freedoms) was adopted, Québec nationalists denounced it since it appeared to give less consideration to Québec's separate cultural identity and more to Canada's bilingual and multicultural identity. In 1987, Prime Minister Brian Mulroney attempted to address some of Québec's concerns with the Meech Lake Accord, an amendment to the Constitution, which guaranteed Québec a number of rights to ensure its separate status within Canada; since the failure of the Accord in 1990, tensions between Québec and the rest of Canada have continued to increase, and some would argue that 'Québécois and English Canadians [are] more divided than ever before' (Balthazar 1995, p.48).

3. Where works have been published in both French and English, I refer to their titles in both languages the first time I make reference to them; subsequent references to them appear in English.

4. Carrier is also very involved in Canadian cultural activities: in addition to serving as the Director of the Canada Council for the Arts (1994-97) and as a consultant to the Canadian Film Development Corporation for six years, he has been advisor to the Québec Minister of Cultural Affairs. He is a Fellow of the Royal Society of Canada and an Officer of the Order of Canada; he coordinated the undergraduate program in Canadian Studies at Collège militaire royal de SaintJean (1973-80); and in 1999 he was named Canada's fourth National Librarian (Beaulieu 2000).

5. While this was true for most of the 1950s, it was not as twe in the 1940s, when the story takes place: despite the fierce rivalry between the two teams, Toronto won the Stanley Cup (see next note) five times that decade, while Montréal won it only twice; this was reversed in the 1950s, when Toronto won the Cup only once, while Montréal won it six times, five of those consecutively - a record in NHL (National Hockey League) history. Roch's perspective here is very childlike, and perhaps also fan-like, in the sense that he appears to remember only the Canadiens' victories.

6. The Stanley Cup is the most important annual award and 'holy grail' for the top hockey team playing in the NHL, which now consists of thirty Canadian and American teams, and is the oldest trophy competed for by athletes in North America. Donated by Governor General Lord Stanley in 1893 for the national Canadian hockey championship played during the 1893-94 season, it was first awarded to the Montréal AAA team, who won the inaugural Stanley Cup game played on 22 March 1894. In terms of hockey mythology, winning 
the Stanley Cup is akin to winning (or retaining) the Ashes in cricket for Britain and Australia, wearing the yellow jersey for the Tour de France, and winning the World Series in baseball or the World Cup in soccer or rugby. Since the formation of the NHL in 1917, the Montréal Canadiens have won the Stanley Cup series twenty times, plus another five times as the Montréal Maroons, more than any other team in hockey; the Toronto Maple Leafs are the second most successful team, having won the Stanley Cup eleven times, plus twice more as the Toronto Arenas and the Toronto St. Pats. During the 1940s, when the story is set and after Maurice Richard joined the Montréal team in 1942, Toronto won the Cup five times, while Montréal won it twice; however, over the next decade, as Richard hit his stride, Montréal won it six times. Their success continued for another twenty years, as they won the Cup four times during the 1960s and six times during the 1970s. Since the first Stanley Cup game in 1893, there has not been a decade during which a Montréal team has not won the Cup at least once.

7. The other teams were the New York Rangers, the Boston Bruins, the Detroit Red Wings, and the Chicago Black Hawks.

8. This echoes Northrop Frye's suggestion that the more closely a work is tied to a particular community, the more national and intemational resonance it will have: 'It seems to be a cultural law that the more specific the setting of literature is, the more universal its communicating power' (1982, p.189).

\section{REFERENCES}

'An evening with Sheldon Cohen'. Osborne and Lillian H. Smith Collection of Children's Books. Toronto Public Library. Toronto, Ontario, Canada. October 1991.

Balthazar, Louis (1995) 'Quebec and the ideal of federalism', The Annals of the American Academy of Political and Social Science 538, March: 40-53.

Beaulieu, Yves (2000) 'Roch Carrier'. National Library of Canada Web Page. http:// www.nlc-bnc.ca/about/carrier-e.htm. 12 July
2000.

Bell, David V.J. (1992) The Roots of Disunity: A Study of Canadian Political Culture. Toronto, Oxford University Press.

Canadian Charter of Rights and Freedoms. P.E. Trudeau, 1982.

Carrier, Roch and Sheldon Cohen (1980) The Sweater. National Film Board of Canada, - (1984) Le Chandail de Hockey. Toronto, Livres Toundra. (1984) The Hockey Sweater. Toronto, Tundra Books.

Frye, Northrop (1982) Divisions on a Ground: Essays on Canadian Culture. Toronto, Anansi.

March, James H. (1985) 'Hockey, ice.' The Canadian Encyclopedia. 2nd ed. 4 vols. Edmonton, Hurtig Publishers, pp.823-24.

Robidoux, Michael A. (2001) Men at Play: A Working Understanding of Professional Hockey. Montreal and Kingston, McGillQueen's University Press.

'Roch Carrier', in Contemporary Literary Criticism (1994). Volume 78. Detroit, Gale Research Inc., pp.36-84.

Thomson, Dale (1995) 'Language, identity, and the nationalist impulse: Quebec', The Annals of the American Academy of Political and Social Science 538, March: 69-82.

Walkley, Max. (1997) 'Roch Carrier, popular language, and "joual", Babel, 32, 2, n.p. http://hsc.csu.edu.au/french/courses/23unit/ options/literat/56/Carrier.html. 10 July, 2000.

\section{BIOGRAPHICAL NOTE}

Canadian Anne Hiebert Alton is Associate Professor of English at Central Michigan University, where she teaches children's and Victorian Literature. Along with articles on P.L. Travers and Diane Duane, she recently published a scholarly edition of Little Women (Broadview). Her chapter on generic fusion in Harry Potter will appear in Harry Potter's World (Routledge) later this year. 